\title{
Modulation of Antioxidant Enzyme Activities by Sexual Steroid Hormones
}

\author{
S. B. PAJOVIĆ ${ }^{1}$, Z. S. SAIČIĆ ${ }^{2}$ \\ ${ }^{1}$ Laboratory of Molecular Biology and Endocrinology, Vinča Institute of Nuclear Sciences, P.O. \\ Box 522, 11001 Belgrade, ${ }^{2}$ Department of Physiology, Institute of Biological Research "Siniša \\ Stanković", University of Belgrade, 11060 Belgrade, Serbia

\section{This minireview is dedicated to the memory of the Academician Prof. Dr. Vojislav M. Petrović}

Received August 15, 2007

Accepted October 22, 2007

On-line November 30, 2007

\section{Summary}

Taking into consideration the biological importance of interaction between antioxidant defense (AD) enzymes and sexual steroid hormones it was deemed important to compare our recent achievements in the field with the state of current knowledge. The main goal of the present review was to investigate the changes of $A D$ enzyme activities: superoxide dismutases, catalase, glutathione peroxidase, glutathione-S-transferase and glutathione reductase in the brain of female and male rats depending on progesterone and estradiol. These ovarian steroids produce their effects by acting on numerous target tissues and organs, such as the reproductive organs, bone tissue and cartilage, peripheral blood vessels and the central nervous system (CNS). We have chosen it as a new parameter that might represent an important indicator of the changes within the CNS, bearing in mind the biological importance of the enzymes of the $A D$ system. Our experimental results indicate that the $A D$ enzyme activities in the brain tissue of female and male rats show a certain dependence on the concentration of progesterone and estradiol. The present review suggests that the modulation of the oxidative and antioxidative capacity by sexual steroid hormones is mediated through antioxidant metabolizing enzymes.

\section{Key words}

Antioxidant defense enzymes • Sexual steroid hormones • Rat • Brain

\section{Corresponding author}

Z. S. Saičić, University of Belgrade, Institute for Biological Research "Sinisa Stankovic", Department of Physiology, Bulevar despota Stefana 142, 11060 Belgrade, Serbia. Fax: (+) 38111 2761 433. E-mail: zorica.saicic@ibiss.bg.ac.yu

\section{Introduction}

Reactive oxygen species (ROS), generated as byproducts of oxidative metabolism in mitochondria, can interact with biomolecules and damage various cellular components. Aerobic organisms developed a complex network of antioxidant defense (AD) system as a protection against harmful effects of ROS in order to maintain tissue homeostasis. The AD system primarily includes the AD enzymes such as: superoxide dismutases (both copper zinc, $\mathrm{CuZn}$ SOD and manganese containing, Mn SOD, EC 1.15.1.1), catalase (CAT, EC 1.11.1.6), glutathione peroxidase (GSH-Px, EC 1.11.1.9), glutathione-S-transferase (GST, EC 2.5.1.18) and glutathione reductase (GR, EC 1.6.4.2). As low molecular weight components we can mention reduced glutathione (GSH), vitamins E and C, flavonoids, etc. (Halliwell and Gutteridge 1999). However, when ROS generation exceeds the antioxidant capacity of cells, oxidative stress develops, potentially causing tissue damage (Araujo et al. 2006). Organization of the AD system is species-, organand tissue-specific and susceptible to alterations in response to both oxidative stress and changes of the 
tissue metabolic activity (Kasapović et al. 2001, Marković et al. 2006, Ognjanović et al. 1995, 2003, Žikić et al. 1996, 1997, 2001, Pajović et al. 1997, 2003, 2006, Saičić et al. 1998, 2006). Specificities of AD system in the brain can be seen not only at the level of its organization, but also at the level of its regulation. In the brain as a central regulatory organ, the balance between free radical production and $\mathrm{AD}$ system is of utmost importance for several reasons. The brain requires about $20 \%$ of total oxygen demand of the body (Nistico et al. 1992). This tissue is characterized by a high rate of oxidative metabolic activity, numerous cell membranes and a high concentration of readily oxidizable substrates (e.g. membrane lipid poyunsaturated fatty acids), high amounts of iron, especially in some regions (Weber, 1994) and endogenous generation of reactive oxygen metabolites by specific neurochemical reactions (monoamine oxidase [MAO; EC 1.4.3.4] catalyzing oxidation of catecholamines), prostaglandin metabolism (Evans 1993), activation of macrophage-type microglial cells (Hall and Broughler 1993) and nitric oxide generation by endothelial cells and neurons (Snyder 1992). In addition, low levels of AD enzymes have been detected in the rat brain in comparison with other tissues (Hothersall et al. 1981, Herman 1983).

Biological effects of the sexual steroid hormones represent the base for many physiological and pathophysiological processes. These hormones, as a group of regulatory molecules produced by the endocrine system, regulate sexual behavior, prepare the organism for reproduction, enable it to adapt to the changes in its environment and regulate ion concentrations in the body fluids. By their selective influence on gene transcription and RNA production, these molecules control the biosynthesis of specific proteins, thus realizing their biological effects at a physiological level (Ing 2005). Steroid hormones can exert their influence even independently of the genome transcription (Kane 1976, Prange et al., Klaiber et al. 1979). The ovarian steroids produce their effects by acting on numerous target tissues and organs, such as the cerebral blood vessels (Stirone et al. 2005).

Bearing in mind these physiological roles of steroids, in relation to the sexual behavior and reproduction, it is easy to see the significance of an intimate understanding of the effects of steroid hormones on the functions of the CNS and the mechanisms behind these effects, which is one of the central aspects of the contemporary neuroendocrinology. A wide range of events, such as the induction of specific receptors, neurotransmitter metabolism, ion transport, enzyme activity etc. are studied as parameters of interactions between steroid hormones and the brain.

The information on the effects of sexual steroid hormones on the enzyme activity inside the brain in the scientific literature is scarce and usually refers to the monoamine oxidase (MAO), acetylcholinesterase (AChE), glucose-6-phosphate dehydrogenase (G-6-PDH), (Luine and Rhodes 1983), as well as tyrosine hydroxylase (TH) (Kritzer and Kohama 1998). It has been demonstrated that the activities of MAO, AChE and G-6$\mathrm{PDH}$ in the preoptical region of the hypothalamus change differently following the treatments with estrogen (E) and progesterone (P). In addition, there are some very interesting results showing that ovariectomy increases the TH activity 2-3 times and that estrogen and progesterone treatments have the opposite effect on the afore mentioned enzyme activity in the hypothalamus. Sobočanes et al. (2003) investigated whether oxidant status and AD activities during ageing of mouse brain are regulated in sex-dependent manner. Throughout ageing, no difference in total superoxide dismutase ( $\mathrm{t}$ SOD) activity between male and female brains was observed, except in immature one-month-old mice. Taken together, their finding indicate that brains of female mice have lower oxidant and higher antioxidant capacity mostly related to CAT and to a lesser extent to GSH-Px activity.

In our studies we have monitored the change of enzyme activity of the AD system in the brain of male and female rats depending on these ovarian steroids (Pajović et al. 1993, 1996, 2003, Pejić et al. 2003). We have chosen it as a new parameter that might represent an important indicator of the changes within the CNS, bearing in mind the biological importance of the enzymes of the $\mathrm{AD}$ system. The study on the activity of the $\mathrm{AD}$ enzymes in the brain of female and male rats in relation to the influence of ovarian hormones can answer whether the action of ovarian steroids on the CNS includes maintenance of a dynamic equilibrium of free radicals in the neurons.

Our experimental results indicate that the enzyme activity of the AD system in the brain tissue of female and male rats shows a certain dependence on the concentration of ovarian hormones, progesterone and estrogen in the organism (Pajović et al. 2003, Michos et al. 2006). This complements the already available information on the effects of hormone action in general and steroid hormones in particular on the enzyme activity 
of the AD system in rat tissues (Pereira et al. 1994, Zarida et al. 1993, Schmidt et al. 2005). Our first information on the influence of steroid hormones on these enzymes in the brain was obtained in the studies by Petrović et al. (1991) and Saičić et al. (1991) investigating the influence of dexamethasone on the activity of $\mathrm{AD}$ enzymes in certain tissues, including the rat brain tissue.

\section{Effects of ovarian hormones on the antioxidant enzyme activities in the female rat brain}

Statistical analysis of the results shows that the activity of CuZn SOD, GST and GR remains stable during the estrous cycle, while the activity of the remaining three enzymes of the $\mathrm{AD}$ system: Mn SOD, which removes superoxide anion radicals $\left(\mathrm{O}_{2}{ }^{-}\right)$inside mitochondria, CAT and GSH-Px, which removes hydrogen peroxide $\left(\mathrm{H}_{2} \mathrm{O}_{2}\right)$ changes depends on the status of ovarian hormones in the organism. During diestrus, CAT activity is increased, while during proestrus $\mathrm{Mn}$ SOD activity increases but GSH-Px activity decreases. These changes can be understood bearing in mind that the concentration of $\mathrm{O}_{2}{ }^{-}$in proestrus is decreased (Laloraya et al. 1988) and that a certain concentration of $\mathrm{H}_{2} \mathrm{O}_{2}$ is necessary at this stage of the cycle, as it bears a distinct physiological role (Laloraya et al. 1989). According to Laloraya et al. (1989) $\mathrm{H}_{2} \mathrm{O}_{2}$ plays the role of a second messenger within the hormonal system which regulates the development of the follicles, the ovulation and the luteal function. In addition, a study monitoring the change of the SOD activity as well as the changes in lipid peroxide (LP) concentration in the corpus luteum of pregnant rats indicated this enzyme activity depends on the concentration of ovarian hormones (Sugino et al. 1993). They have shown that the activities of Mn SOD and CuZn SOD gradually increase until the 15th day of the pregnancy coinciding with the change in serum progesterone levels. The concentration of LP is decreased until the 15th day of pregnancy, but it rises sharply between the 15 th and 21 st day which is expected considering that the peroxides have an essential role in the regression of the corpus luteum. Hence, the authors came to a general conclusion that SOD and LP play an important role in the regulation of the luteal function during pregnancy.

We have demonstrated that compared to the AD enzyme activities inside the brain of intact female animals with normal cycles, bilateral ovariectomy was ineffective only regarding $\mathrm{CuZn}$ SOD activity. Prolonged absence of the ovaries leads to a significant increase of Mn SOD, CAT, GSH-Px and GST activities, while the GR activity is decreased. The mid-day increase of Mn SOD activity in proestrus of intact females or animals that have been subjected to an ovariectomy, as well as the decrease of the activity of this enzyme in the brain of animals subjected to ovariectomy but treated with ovarian steroids, coincide with the changes characteristic for the secretion of gonadotropins by the pituitary gland during the estrous cycle and following a bilateral ovariectomy. It is, therefore, necessary to examine these observed changes as possible consequences of indirect action of ovarian hormones, exerted through the change in gonadotropin secretion. It is well known that the tonic secretion of luteinizing hormone (LH) and follicle stimulating hormone (FSH) is followed by a sudden release of these hormones into the circulation around noon and in the early afternoon during the proestrus (Brown-Grant et al. 1970, Kalra et al. 1971, Butcher et al. 1974). Preovulatory release of gonadotropins during proestrus is an essential requirement for the rupture of mature follicles and ovulation. It is also known that the inhibitory effect on secretion of gonadotropins results in the tonic circulatory concentrations of these hormones; with the removal of ovaries this inhibition is abolished and the concentrations of $\mathrm{LH}$ and FSH in the circulation gradually rise to reach a ten-fold value and a plateau 2-3 weeks after the ovariectomy (Tapper et al. 1974). If the animals, which have been subjected to ovariectomy, are treated with exogenous progesterone, LH and FSH concentrations in the blood decrease rapidly (24-48 h) to the tonic levels.

It is known that gonadotropins can act as mediators of the influence of the ovarian hormones on enzyme activity. For example, Laloraya et al. (1988) have demonstrated a specific induction of SOD activity by lutropin in rat ovaries. Considering that the effects of lutropin can be blocked using anti-LH serum, it is evident that lutropin is a functional analogue of LH. New research showing the presence of $\mathrm{LH}$ in the extrahypothalamical structures seems to support the hypothesis of an indirect effect of ovarian steroids, achieved through LH on the Mn SOD activity in the brain of the female rats. Using radioimmunological analysis and chromatography Emanuele et al. (1983) have shown the presence of $\mathrm{LH}$ in the anterior lobe of the pituitary gland, amygdala, thalamus, cerebellum, hippocampus, nucleus caudatus and cortex. Immunoreactive $\mathrm{LH}$ in the 
extrahypothalamical structures has also been detected by Hostetter et al. (1987). The question as to whether LH inside the extrahypothalamical structures originates from the hypothalamus (reaching it via retrograde transport from the pituitary gland) or if it is synthesized de novo inside these structures remains unanswered. The fact that the concentration of $\mathrm{LH}$ inside the extrahypothalamical structures does not change following hypophysectomy, while it decreases in serum to undetectable levels, seems to support the thesis of de novo synthesis (Kalra and Kalra 1977). Regardless of its unexplained origin, the presence of LH in brain tissues outside of hypothalamus indicates that it might have an intermediary role in the realization of the effects of ovarian steroids, not only on the activity of Mn SOD, but also on the activity of other antioxidant defense enzymes. Besides the available information on LH, there is also some research describing the effects of other gonadotropins on the SOD activity. For example, Sato et al. (1992) have shown that treating rats with serum gonadotropin of a pregnant mare and human chorionic gonadotropin results in a significant decrease of the Mn SOD activity inside the ovary, while the CuZn SOD activity remains unchanged.

The question that arises next, whether the effects of progesterone and estrogen on the Mn SOD activity in the brain are direct, or are achieved through an intermediary, i.e. through $\mathrm{LH}$ or FSH secretion, is a logical one, since the changes in the activity not only coincide with the described changes in the gonadotropin secretion, but are also of the same direction.

After a certain time period, bilateral ovariectomy results in a significant increase in CAT activity, while hormonal treatments bear no effect on the activity of this enzyme. We can, therefore, assume that the effect of progesterone and estrogen on CAT activity in the brain is achieved through an intermediary, i.e. through gonadotropin secretion. A significant increase in CAT activity during the estrous cycle has been observed in diestrus, which is understandable considering that CAT is predominantly located in microperoxisomes in the hypothalamus (which is the target tissue for $\mathrm{LH}$ in a short positive feedback mechanism) and that the changes of $\mathrm{LH}$ concentrations in the serum, hypothalamus and extrahypothalamical structures do not necessarily have to be in the same direction (Kalra and Kalra 1977).

Unlike the CAT, GSH-Px is found in all parts of the CNS. Since ovariectomy increases the GSH-Px activity, as does the treatment with $2 \mathrm{mg}$ of progesterone after $24 \mathrm{~h}$, the activity of this enzyme can be modulated in two ways: 1) by changing the level of progesterone and 2 ) by changing the level of gonadotropins. The results showing that the activity of GSH-Px is decreased in the morning of proestrus, before the sudden LH and FSH release (Brown-Grant et al. 1970) and while progesterone is at a lower level in comparison with the other phases of the estrous cycle (Butcher et al. 1974, Sodersten et al. 1981) seem to substantiate this hypothesis. On the other hand, in the case of selenium-independent GSH-Px, GST, a significant increase of activity has been observed only in the brain of the animals that have been subjected to ovariectomy, which coincides with the drastic change in the level of gonadotropins (Tapper et al. 1974). Therefore, contrary to the selenium-dependent GSH-Px, GST activity can be modulated only in one way by changing the level of gonadotropins. In neither of the phases of the estrous cycle, not even during early proestrus, there will be such a drastic increase of gonadotropins (like the one that occurs at a certain time after the ovariectomy) which would influence GST activity.

In the case of GR, the third enzyme in the glutathione redox cycle, ovariectomy results in a significant decrease of its activity. The results of a hormonal treatment are very interesting, since they point to a divergence in the effects that the hormones have on the activity of GR. The effects are opposite, the inhibitory effect of the estrogen on GR activity is detectable after $2 \mathrm{~h}$ and will disappear after $24 \mathrm{~h}$, while the stimulatory effect of progesterone is achieved only $24 \mathrm{~h}$ after the treatment. Bearing in mind this difference in hormonal treatments, as well as the fact that the removal of the primary source of ovarian hormones results in a decrease of GR activity, it can be assumed that GR activity can be modulated directly by changing the level of ovarian hormones.

\section{Sexual dimorphism in the antioxidant enzyme activities in the rat tissue}

There are some particularly interesting studies that refer to the sexual dimorphism in the activity of AD enzymes in different rat tissues (Prohaska and Sunde 1993, Kasapović et al. 1997, 2001, Azevedo et al. 2001, Tam et al. 2003). Pinto and Bartley (1969) have demonstrated that the CAT activity in rat liver is significantly higher in males than in females. Capel and Smallwood (1983) have examined whether there are any sexual differences in the GSH-Px activities in rat brain, 
liver and blood. They have shown that there is no significant difference in GSH-Px activity in the brain between males and females, while in the liver the activity of this enzyme is significantly higher in females than in males. The observed difference in GSH-Px activity in the blood of male and female rats has no physiological consequence. Prohaska and Sunde (1993) have also demonstrated that the GSH-Px activity in rat liver is higher in females than in males, which is understandable considering that mRNA levels, as well as selenium concentrations, are much higher in female than in male rats. In our further study, carried out in a series of experiments on males, both intact and subjected to orchidectomy, untreated and treated with ovarian steroids, we have attempted to find out whether there is a sex difference in the response to the administered hormonal treatment. Unlike the ovariectomy in females, the orchidectomy has no effect on the activity of either cytosolic or mitochondrial SOD. CuZn SOD activity does not change even after the hormonal treatment. However, $2 \mathrm{mg}$ of progesterone or $5 \mu \mathrm{g}$ of estradiol benzoate (EB) decrease the Mn SOD activity both $2 \mathrm{~h}$ and $24 \mathrm{~h}$ after the treatment, but do not display a synergistic effect. Since it is known that the orchidectomy results in an increase of serum LH concentration in comparison with intact animals and that it has no effect on the SOD activity, it is logical to assume that the ovarian hormones influence the activity of the mitochondrial SOD in the brain of a male rat directly. The results of hormonal treatments support this hypothesis. Special attention should be paid to the absence of a synergistic effect of hormones on the SOD activity. This indicate that these hormones induce their effects directly through their distinct receptors. It has been demonstrated in rats and guinea pigs that there is an overlap in the autoradiographic maps of receptors for estrogen and progesterone (Sar and Stumpf 1973) in the hypothalamus of these animals.

\section{Comparisons of the hormonal modulation of antioxidant enzyme activities in the male and female rat brain}

The effect of ovarian hormones on the SOD activity in the brain of male and female rats seems to be uniform. However, the analysis of hormonal treatments, ovariectomy or orchidectomy effects, indicates that the mechanisms of action of ovarian steroids on the SOD activity in the brain of male and female rats are different. It appears that the effects of the ovarian steroids on the enzyme activity in the brain of male animals are direct, while in the brain of the female animals these effects are achieved indirectly, through the change in the gonadotropin levels. No sexual dimorphism was observed in the specific SOD activity in the brain of intact female and male rats. Prohaska and Sunde (1993) studied the activity of CuZn SOD in the liver in relation to the sex and have come to the conclusion that there is also no sexual dimorphism in the level of CuZn SOD activity.

Since the orchidectomy does not influence the CAT activity and ovarian steroids increase it (EB $2 \mathrm{~h}$ and progesterone $24 \mathrm{~h}$ following the treatment) it can be concluded that this enzyme is more sensitive to the direct influence of the sexual steroids in the male brain compared to the same enzyme activity in the female brain which is only changed after a certain time following bilateral ovariectomy resulting in a drastic increase in gonadotropin levels. Modulation of the SOD and CAT activity in the CNS is extremely important considering that the presence of these two enzymes controls ROS level, which, in turn, directly affect the permeability of the blood-brain barrier (Armstead et al. 1992). Pinto and Bartley (1969) have shown that the CAT activity is higher in the liver tissue of male animals than in the same tissue of female animals. Following a statistical analysis of our results we have shown that this conclusion applies to the brain tissue as well. Specific CAT activity is significantly increased in the brain of the male rats compared to that of the intact female rats regardless of the phase of the estrous cycle.

As is the case of CAT the orchidectomy has no effect on the GSH-Px activity. Treatments with progesterone does not affect it either, while EB suppresses the activity $2 \mathrm{~h}$ after the treatment, but this effect will not be maintained $24 \mathrm{~h}$ later. Since orchidectomy has no effect in this case either, unlike ovariectomy, which significantly increases the activity in the brain of female animals, it is probable that the GSHPx activity is modulated directly by the changes in EB levels. This effect is short-lived. It can thus be concluded that the GSH-Px in the brain of female rats is more sensitive to the changes in gonadotropin levels compared to the same enzyme in the brain of male animals. Statistical comparison of the specific GSH-Px activity in the brains of intact female and male rats has shown that the GSH-Px activity in the brain of the males was significantly increased compared to the same enzyme activity in the brain of the intact females regardless of the phase of the estrous cycle (Saičić et al. 1998, Pajović et 
al. 1999). Finley and Kincaid (1991) studied sex dependence of the selenium content and plasma GSH-Px activity in plasma, erythrocytes and kidney cytosol. They have demonstrated that the selenium content and GSH-Px activity are increased in the plasma and kidney cytosol, but decreased in the liver cytosol of the male animals compared to the same tissues in female animals.

Unlike the other enzymes of the AD system, GST activity is significantly increased following orchidectomy. Treatment with progesterone has no influence, while EB only decreases GST activity $24 \mathrm{~h}$ after the treatment. Therefore, unlike GSH-Px activity, which can only be modulated by modifying EB levels, GST activity in the brain of male animals can be modulated in two ways: by modifying EB levels and by modifying gonadotropin levels. This is different than the GST activity in the brain of female animals which changes only after a bilateral ovariectomy, when the LH and FSH levels increase severely over the 2-3 weeks. A comparison of the specific activities of cerebral GST in intact females and males indicates that this enzyme activity does not depend on the sex of the animal. Al-Turk et al. (1987) have reported that the content of GSH, GST and GR activities in the erythrocytes and lymphocytes of men and women do not depend on the sex. Our results also show that the GR activity in the brain of male rats is not significantly different than the GR activity in the brain of intact female rats. Orchidectomy does not influence the GR activity, while it takes $24 \mathrm{~h}$ for EB to show a significant suppression of this enzymatic activity. Therefore, GR activity in the brain of male rats, as well as the brain of female rats, is modulated directly by modifying steroid levels. However, it should be emphasized that the GR in the brain of female rats is sensitive to the changes in levels of both types of ovarian steroids, unlike the GR in the brain of male rats, which only changes depending on the EB levels. Also, the effect that EB has on GR activity in the brain of the females is clearly visible just $2 \mathrm{~h}$ following the treatment, but it is short-lived and is not present $24 \mathrm{~h}$ later. On the other hand, the effect that EB has on GR activity in the brain of the males is not as fast, and can only be clearly detected $24 \mathrm{~h}$ after the treatment.

It has been said that the dependence of the enzymatic activity of the AD system in the brain of female rats on the level of ovarian hormones, progesterone and estrogen is probably based on the indirect effects of the ovarian steroids achieved through the changes in gonadotropin levels. On the other hand, enzymatic activity of the AD system in the brain of male animals is also dependent, to a certain extent, on the ovarian hormone levels, although the direct modulation of enzymatic activity is more pronounced in males. This can be explained by the differences in gonadotropin secretion between the sexes. It is well known that the change of LH and FSH concentrations in the serum is an estrogen-dependent process in female and estrogenindependent process in male rats. This phenomenon was described by Saade et al. (1987) in their study of the effect of $17 \beta-E B$ on the hypothalamic-pituitary system of intact males in which they noticed that $\mathrm{LH}$ response to luteinizing hormone releasing hormone (LHRH) was not modulated by estrogen, not even 7 days after the treatment. Similarly, Chen (1988) demonstrated that all secretory cells of female rats containing LH secrete the LH under the influence of gonadotropin releasing hormone $(\mathrm{GnRH})$ while only a small number of pituitary cells in males secrete LH. Chen (1988) assumed that the increased number of pituitary cells secreting LH under the influence of GnRH in female rats, compared to male rats, was a result of the estrogen influence on the hypothalamic-pituitary system.

When the sensitivity of certain enzymes of the AD system to particular hormones is concerned, the following conclusions be drawn: a) in the brain of the females, only Mn SOD and GR show the sensitivity to both hormones. Thus, in the case of Mn SOD, progesterone and EB act in the same manner, suppressing the activity of the mitochondrial SOD. On the other hand, in the case of GR the effects of progesterone and EB are different. GSH-Px activity is changed only by modulating the concentrations of progesterone; and $b$ ) in the brain of male animals, MnSOD and CAT activity changes depend on the levels of both hormones. Both progesterone and EB act on the Mn SOD and CAT activity in the same manner because both decrease the activity of the mitochondrial SOD and increase the CAT activity in the brain. GSH-Px, GST and GR activities are suppressed by EB.

If the $\mathrm{AD}$ system of the female animals is examined to see in which direction each of the hormones modulates the activity of individual AD enzymes, a certain logic emerges in their relationships. Being that Mn SOD activity decreases under the influence of progesterone the production of $\mathrm{O}_{2}{ }^{--}$radicals and $\mathrm{H}_{2} \mathrm{O}_{2}$ is increased explaining the increase of the GSH-Px activity (which removes excess $\mathrm{H}_{2} \mathrm{O}_{2}$ ) under the influence of progesterone. As GSH-Px uses reduced GSH, the 
induction of GR as a consequence of progesterone treatment is also understandable. However, it is interesting that EB suppresses Mn SOD activity (thus increasing the concentration of $\mathrm{O}_{2}{ }^{--}$radicals), but has no effect on any of the enzymes which remove the excess $\mathrm{H}_{2} \mathrm{O}_{2}$ (CAT, GSH-Px and GST), while it even reduces the GR activity, probably because of the decreased consumption of its substrate - GSH. Perhaps this effect of EB on the enzymes of the AD system is one of the causes for the development of tumors in the animals that have been chronically treated with EB (Crooke et al. 2006).

Within the $\mathrm{AD}$ system of males, progesterone decreases the Mn SOD activity just as it does in females, but at the same time increases the CAT activity (but not the activity of GSH-Px as in females), which removes the excess $\mathrm{H}_{2} \mathrm{O}_{2}$. Progesterone does not influence other enzymes in the AD system in the brain of male animals. On the other hand, EB has the same effect on the Mn SOD and CAT activity as does progesterone, but it also causes a significant suppression of the enzymes of the GSH redox cycle, which similarly to the situation in females increases the probability of excess $\mathrm{H}_{2} \mathrm{O}_{2}$ formation.

The difference in effects of progesterone and EB on the activity of the mitochondrial and cytosolic SOD has raised the question of the possible site of ovarian steroid action in the control of the activity of the observed enzymes (Pajović et al. 1994a). We attempted to find the answer in an experiment on isolated synaptosomal fraction because synaptosomes isolated from nerve endings are rich in mitochondria (Alnaes and Rahamimoff 1975, Pajović et al. 1994b) which are the site of the intensive oxidative processes (Turrens 2003). We assumed and later confirmed that the inhibitory effect of studied hormones on the SOD activity will be more pronounced in the synaptosomal fraction in comparison to the effect observed in the homogenate of the whole brain. In these experiments on the isolated synaptosomal fraction from the whole brain of a female rat we have demonstrated that the above mentioned dependency applies not only to the Mn SOD but also to the cytosolic SOD, CuZn SOD. During these experiments we found that both ovarian hormones suppress the Mn SOD activity and they have a significant synergistic effect on this enzymatic activity. In the same way, EB modulates the activity of the cytosolic SOD. Progesterone has no influence on the $\mathrm{CuZn} \mathrm{SOD}$ activity if it is used on its own, but modulates CuZn SOD activity only in animals previously treated with EB. This effect of the EB is analogue to the well-known "priming" effect (Thornton et al 1986, Jones et al. 1987) and shows that this hormone is a regulatory factor of progesterone action in the case of $\mathrm{AD}$ enzyme activity in the CNS of female rats as well. Considering that the suppressing effect of the ovarian steroids in the purified synaptosomal fraction, rich in mitochondria, on both mitochondrial and cytosolic SOD is very pronounced, it is reasonable to assume that the mitochondria is an important site of action, not only for glucocorticoids (Demonacos et al. 1993), but also for ovarian steroids (Pajović et al.1994b, Duckles et al. 2006, Duckles and Krause 2007).

\section{Conclusions}

The data presented in this review suggest endogenous pattern of antioxidant defense enzyme expression which could be modulated by sexual steroid hormones. Under the normal physiological conditions, there is a critical balance in the generation of oxygen free radicals and antioxidant defense system used by organisms to deactivate and protect themselves against free radical toxicity. The pro-oxidant/antioxidant balance and detoxification of potentially damaging ROS is crucial for cellular homeostasis. The modulation of antioxidant enzymes activities during and after hormonal treatment is related to the changes on the level of neuroendocrine and oxidative status in the brain tissue.

\section{Conflict of Interest}

There is no conflict of interest.

\section{Acknowledgements}

This study was supported by the Ministry of Science and Technological Development of Republic of Serbia, Grant No. 143035B.

\section{Abbreviations}

AChE (acetylcholinesterase), AD (antioxidant defense), CAT (catalase), CNS (central nervous system), CuZn SOD (copper zinc containing superoxide dismutase), E (estrogen), EB (estradiol benzoate), FSH (follicle stimulating hormone), G-6-PDH (glucose-6-phosphate dehydrogenase), GnRH (gonadotropin releasing hormone), GR (glutathione reductase), GSH (reduced glutathione), GSH-Px (glutathione peroxidase), GST (glutathione-S-transferase), $\mathrm{H}_{2} \mathrm{O}_{2}$ (hydrogen peroxide), LH (luteinizing hormone), LHRH (luteinizing hormone releasing hormone), LP (lipid peroxide), MAO 
(monoamine oxidase), Mn SOD (manganese containing superoxide dismutase), mRNA (messenger ribonucleic acid), $\mathrm{O}_{2}{ }^{--}$(superoxide anion radicals), $\mathrm{P}$ (progesterone),
RNA (ribonucleic acid), ROS (reactive oxygen species), TH (tyrosine hydroxylase), t SOD (total superoxide dismutase)

\section{References}

ALNAES E, RAHAMIMOFF R: On the role of mitochondria in transmitter release from motor nerve terminals. J Physiol Lond 248: 285-306, 1975.

AL-TURK WA, STOHS SJ, EL-RASHIDY FH, OTHMAN S, SHAHEEN O: Glutathione, glutathione S-transferase and glutathione reductase in human erythrocytes and lymphocytes as a function of sex. Drug Des Deliv 1: 237 $243,1987$.

ARAUJO ASR, RIBEIRO MFM, ENZVEILER A, SCHENKEL P, FERNANDES TRG, PARTATA WA, IRIQOYEN MC, LLESUY S, BELLÓ-KLEIN, A: Myocardial antioxidant enzyme activities and concentration and glutathione metabolism in experimental hyperthyroidism. Mol Cell Endocrinol 249: 133-139, 2006.

ARMSTEAD WM, MIRRO R, THELIN OP, SHIBATA M, ZUCKERMAN SL, SHANKLIN DR, BUSIJA DW, LEFFLER CW: Polyethylene glycol superoxide dismutase and catalase attenuate increased blood-brain barrier permeability after ischemia in piglets. Stroke 23: 755-762, 1992.

AZEVEDO RB, LACAVA ZGM, MIYASAKA CK, CHAVES SB, CURI R: Regulation of antioxidant enzyme activities in male and female rat macrophages by sex steroids. Braz J Med Biol Res 34: 683-687, 2001.

BROWN-GRANT K, EXLEY D, NAFTOLIN F: Peripheral plasma oestradiol and luteinizing hormone concentrations during the oestrous cycle of the rat. J Endocrinol 48: 295-296, 1970.

BUTCHER RL, COLLINS WE, FUGO NW: Plasma concentration of LH, FSH, prolactin, progesterone and estradiol$17 \beta$ throughout the 4-day estrous cycle of the rat. Endocrinology 94: 1704-1708, 1974.

CAPEL ID, SMALLWOOD AE: Sex differences in the glutathione peroxidase activity of various tissues of the rat. Ress Commun Chem Pathol Pharmacol 40: 367-378, 1983.

CHEN T: Sexual dimorphism of pituitary gonadotropes during postnatal development in the rat. Mol Cell Endocrinol 57: 33, 1988.

CROOKE PS, RITCHIE MD, HACHEY DL, DAWLING S, ROODI N, PARL FF: Estrogens, enzyme variants and breast cancer: a risk model. Cancer Epidemiol Biomarkers Prev 15: 1620-1629, 2006.

DEMONACOS C, TSAWDAROGLOU NC, ĐORĐEVIĆ-MARKOVIĆ R, PAPALOPOULOU M, GALANOPOULOS V, PAPADOGEORGAKI S, SEKERIS CE: Import of the glucocorticoid receptor into rat liver mitochondria in vivo and in vitro. J Steroid Biochem Mol Biol 46: 401-413, 1993.

DUCKLES SP, KRAUSE DN: Cerebrovascular effects of oestrogen: multiplicity of action. Clin Exp Pharmacol Physiol 34: 801-808, 2007.

DUCKLES SP, KRAUSE DN, STIRONE C, PROCACCIO V: Estrogen and mitochondria: a new paradigm for vascular protection? Mol Interv 6: 26-35, 2006.

EMANUELE NV, ANDERSON J, ANDERSON E, CONNICK E, BAKER G, KIRSTEINS L, LAWRENCE AM: Extrahypothalamic brain luteinizing hormone: characterization by radioimmunoassay, chromatography, radioligand assay and bioassay. Neuroendocrinology 36: 254-260, 1983.

EVANS PH: Free radicals in brain metabolism and pathology. Br Med Bull 49: 577-587, 1993.

FINLEY JW, KINCAID RL: Effects of sex and time of sampling on selenium and glutathione peroxidase activity in tissues of mature rats. Biol Trace Elem Res 29: 181-191, 1991.

HALL ED, BROUGHLER JM: Free radicals in CNS injury. In: Molecular and Cellular Approaches in the Treatment of Neurological Diseases, SG WAXMAN (ed), Raven Press, New York, 1993, pp 81-103.

HALLIWELL B, GUTTERIDGE JMC (eds): Free Radicals in Biology and Medicine. Oxford University Press, New York, 1999.

HERMAN D: Free radical theory of aging: consequences of mitochondrial aging. Age 6: 86-94, 1983.

HOSTETTER G, EATON A, CAMES M, GILDNER J, BROWNFIELD MS: Immunocytochemical distribution of luteinizing hormone in rat central nervous system. Neuroendocrinology 46: 185-193, 1987. 
HOTHERSALL JS, EL HASAN A, MCLEAN P, GREENBAUM AL: Age-related changes in enzymes of rat brain. 2. Redox system linked to NADH and glutathione. Enzyme 26: 271-276, 1981.

ING NH: Steroid hormones regulate gene expression posttranscriptionally by altering the stabilities of messenger RNAs. Biol Reprod 72: 1290-1296, 2005.

JONES JJ, MCEWEN BS, PFAFF DW: Quantitative assessment of the synergistic and independent effects of estradiol and progesterone on ventromedial hypothalamic and preoptic-area proteins in female rat brain. Metab Brain Dis 2: 4, 1987.

KALRA PS, KALRA SP: Temporal changes in the hypothalamic and serum luteinizing hormone-releasing hormone (LH-RF) levels and the circulating ovarian steroids during the rat oestrus cycle. Acta Endocrinol 85: 449-455, 1977.

KALRA SP, AJIKA K, KRULICH L, FAWCETT CP, QUIJADA M, MCCANN SM: Effects of hypothalamic and preoptic electrochemical stimulation on gonadotropin and prolactin release in proestrus rats. Endocrinology 88: 1150-1158, 1971.

KANE FJ: Evaluation of emotional-reactions to oral contraceptive use. Am Obstet Gynecol 126: 968-972, 1976.

KASAPOVIĆ J, PAJOVIĆ SB, KANAZIR DT, MARTINOVIĆ JV: Effects of estradiol benzoate and progesterone on superoxide dismutase activity in the rat liver. $J$ Endocrinol Invest 20: 203-206, 1997.

KASAPOVIĆ J, PAJOVIĆ SB, PEJIĆ S, MARTINOVIĆ JV: Effects of estradiol benzoate and progesterone on superoxide dismutase activity in the thymus of rats. Physiol Res 50: 97-103, 2001.

KLAIBER EL, BROVERMAN DM, VOGEL W, KOBAYASHI T: Estrogen therapy for severe persistent depressions in women. Arch Gen Psychiat 36: 550-554, 1979.

KRITZER MF, KOHAMA SG: Ovarian hormones influence the morphology, distribution and density of tyrosine hydroxylase immunoreactive axons in the dorsolateral prefrontal cortex of adult rhesus monkeys. $J$ Comp Neurol 395: 1-17, 1998.

LALORAYA M, KUMAR GP, LALORAYA MM: Changes in the levels of superoxide anion radical and superoxide dismutase during the estrous cycle of rattus norvegicus and induction of superoxide dismutase in rat ovary by lutropin. Biochem Biophys Res Commun 157: 146-153, 1988.

LALORAYA M, KUMAR GP, LALORAYA MM: Histochemical study of superoxide dismutase in the ovary of the rat during the oestrous cycle. J Reprod Fertil 86: 583-587, 1989.

LUINE VN, RHODES JC: Gonadal hormone regulation of MAO and other enzymes in hypothalamic areas. Neuroendocrinology 36: 235-241, 1983.

MARKOVIĆ SD, OGNJANOVIĆ BI, ŠTAJN AŠ, ŽIKIĆ RV, SAIČIĆ ZS, RADOJIČIĆ RM, SPASIĆ MB: The effects of nitroglycerine on the redox status of rat erythrocytes and reticulocytes. Physiol Res 55: 389-396, 2006.

MICHOS C, KIORTSIS DN, EVANGELOU A, KARKABOUNAS S: Antioxidant protection during the menstrual cycle: the effects of estradiol on ascorbic-dehydroascorbic acid plasma levels and total antioxidant plasma status in eumenorrhoic women during the menstrual cycle. Acta Obstet Gynecol Scand 85: 960-965, 2006.

NISTICO G, CIRIOLO MR, FISKIN K, IANNONE M, DE MARTINO A, ROTILIO G: NFG restores decrease in catalase activity and increase superoxide dismutase activity in the brain of aged rats. Free Radic Biol Med 12: 177-181, 1992.

OGNJANOVIĆ B, ŽIKIĆ RV, ŠTAJN A, SAIČIĆ ZS, KOSTIĆ MM, PETROVIĆ VM: The effects of selenium on the antioxidant defense system in the liver of rats exposed to cadmium. Physiol Res 44: 293-300, 1995.

OGNJANOVIĆ B, PAVLOVIĆ SZ, MALETIĆ SD, ŽIKIĆ RV, ŠTAJN AŠ, RADOJIČIĆ RM, SAIČIĆ ZS, PETROVIĆ VM: Protective influence of vitamin E on antioxidant defense system in the blood of rats treated to cadmium. Physiol Res 52: 563-570, 2003.

PAJOVIĆ S, NIKEZIĆ G, MARTINOVIĆ JV: Effects of ovarian steroids on superoxide dismutase activity in the rat brain. Experientia 49: 73-75, 1993.

PAJOVIĆ S, NIKEZIĆ G, MARTINOVIĆ JV: Effects of estradiol and progesterone on superoxide dismutase activity in the rat hypothalamus. Neuroendocrinol Lett 16: 35-40, 1994a.

PAJOVIĆ S, NIKEZIĆ G, MARTINOVIĆ JV: Effects of ovarian hormones superoxide dismutase activity in rat brain synaptosomes. Neuroendocrinol Lett 16: 291-296, 1994b. 
PAJOVIĆ S, SAIČIĆ ZS, SPASIĆ MB, PETROVIĆ VM, MARTINOVIĆ JV: Effects of progesterone and estradiol benzoate on superoxide dismutase activity in the brain of male rats. Experientia 52: 221-224, 1996.

PAJOVIĆ SB, KASAPOVIĆ J, MARTINOVIĆ J: Superoxide dismutase activities in different tissues of female rats treated with olive oil. Physiol Res 46: 381-384, 1997.

PAJOVIĆ SB, SAIČIĆ ZS, SPASIĆ MB, PETROVIĆ VM, MARTINOVIĆ JV: Effects of progesterone and estradiol benzoate on glutathione dependent antioxidant enzyme activities in the brain of female rats. Gen Physiol Biophys 18: 35-44, 1999.

PAJOVIĆ SB, SAIČIĆ ZS, SPASIĆ MB, PETROVIĆ VM: The effect of ovarian hormones on antioxidant enzyme activities in the brain of male rats. Physiol Res 52: 189-194, 2003.

PAJOVIĆ SB, PEJIĆ S, STOJILJKOVIĆ V, GAVRILOVIĆ LJ, DRONJAK S, KANAZIR DT: Alterations in hippocampal antioxidant enzyme activities and sympatho-adrenomedullary system of rats in response to different stress models. Physiol Res 55: 453-460, 2006.

PEJIĆ S, KASAPOVIĆ J, CVETKOVIĆ D, PAJOVIĆ SB: The modulatory effect of estradiol benzoate on superoxide dismutase activity in the developing rat brain. Braz J Med Biol Res 36: 579-586, 2003.

PEREIRA B, ROSA FBPC, SAFI DA, BECHARA EJH, CURI R: Control of superoxide dismutase, catalase and glutathione peroxidase activities in rat lymphoid organs by thyroid hormones. $J$ Endocrinol 140: 73-77, 1994.

PETROVIĆ VM, SAIČIĆ ZS, SPASIĆ M, RADOJIČIĆ R, BUZADŽIĆ B: Hormones and antioxidant defense. In: Anticarcinogenesis and Radiation Protection 2, FO NYGAARD, CA UPTON (eds), Plenum Press, New York, 1991, pp 405-413.

PINTO RE, BARTLEY W: The nature of teh sex-linked differences in glutathione peroxidase activity and aerobic oxidation of glutathione in male and female rat liver. Biochemistry 115: 449-456, 1969.

PRANGE AJ, LIPTON MA, NEMEROFF CB, WILSON IC: Role of hormones in depression. Life Sci 20: 1305-1318, 1977.

PROHASKA JR, SUNDE RA: Comparison of liver glutathione peroxidase activity and messenger RNA in female and male mice and rats. Comp Biochem Physiol B 105: 111-116, 1993.

SAADE G, LONDON DR, CLAYTON RN: Effects of oestrogen treatment on gonadotropin function in adult male rats. J Endocrinol 114: 95-101, 1987.

SAIČIĆ ZS, SPASIĆ M, RADOJIČIĆ R, PETROVIĆ VM: The effect of dexamethasone on the antioxidant enzymes in the blood of rats. In: Anticarcinogenesis and Radiation Protection 2, FO NYGAARD, CA UPTON (eds), Plenum Press, New York, 1991, pp 414-416.

SAIČIĆ ZS, PAJOVIĆ SB, KORAĆ B, SPASIĆ MB, MARTINOVIĆ JV, PETROVIĆ VM: Glutathione-dependent antioxidant enzyme activities and glutathione content in the rat brain at different stages of oestrous cycle. Physiol Res 47: 61-67, 1998.

SAIČIĆ ZS, MIJALKOVIĆ DN, NIKOLIĆ AL, BLAGOJEVIĆ DP, SPASIĆ MB: Effect of thyroxine on antioxidant defense system in the liver of different aged rats. Physiol Res 55: 561-568, 2006.

SAR M, STUMPF WE: Neurons of the hypothalamus concentrate H-progesterone or its metabolite. Science 182: 1266$1268,1973$.

SATO EF, KOBUCHI H, EDASHIGE K, TAKAHASHI M, YOSHIOKA T, UTSUMI K, INOUE M: Dynamic aspects of ovarian superoxide dismutase isozymes during the ovulatory process in the rat. FEBS Lett 303: 121-125, 1992.

SCHMIDT AJ, KRIEG JC, VEDDER H: Effects of steroid hormones on catalase activity in neuronal and glial cell systems. Eur Neuropharmacol 15: 177-183, 2005.

SNYDER SH: Nitric oxide: First in a new class of neurotransmitters? Science 257: 494-496, 1992.

SOBOČANES S, BALOG T, ŠVERKO V, MAROTTI T: Sex-dependent antioxidant enzyme activities and lipid peroxidation in ageing mouse brain. Free Radic Res 37: 743-748, 2003.

SODERSTEN P, ENEROTH P, HANSEN S: Induction of sexual receptivity in ovariectomized rats by pulse administration of oestradiol-17ß. J Endocrinol 89: 55-62, 1981.

STIRONE C, DUCKLES SP, KRAUSE DN, PROCACCIO V: Estrogen increases mitochondrial efficiency and reduces oxidative stress in cerebral blood vessels. Mol Pharmacol 68: 959-965, 2005. 
SUGINO N, NAKAMURA TO, ISHIMATSU M, KATO H: Changes in activities of superoxide dismutase and lipid peroxide in corpus luteum during pregnancy in rats. J Reprod Fertil 97: 347-351, 1993.

TAM NNC, GHATAK S, HO SM: Sex hormone-induced alterations in the activities of antioxidant enzymes and lipid peroxidation status in the prostate of noble rats. Prostate 55: 1-8, 2003.

TAPPER CM, GRIEG F, BROWN-GRANT K: Effects of steroid hormones on gonadotropin secretion in female rats after ovariectomy during the oestrous cycle. J Endocrinol 62: 511-525, 1974.

THORNTON JE, NOCK B, MCEWEN BS, FEDER HH: Estrogen induction of progestin receptors in microdissected hypothalamic and limbic nuclei of female quinea pigs. Neuroendocrinology 43: 182-188, 1986.

TURRENS J: Mitochondrial formation of reactive oxygen species. J Physiol Lond 552: 335-344, 2003.

WEBER GF: The pathophysiology of reactive oxygen intermediates in the central nervous system. Med Hypotheses 43: 223-230, 1994.

ZARIDA H, NGAH WZW, KHALID BAK: Effect of gonadectomy and sex hormones replacement on glutathione related enzymes in rats. Asia Pacific J Pharmacol 8: 223-230, 1993.

ŽIKIĆ RV, ŠTAJN A, SAIČIĆ ZS, SPASIĆ MB, ZIEMNICKI K, PETROVIĆ VM: The activities of superoxide dismutase, catalase and ascorbic acid content in the liver of goldfish (Carassius auratus gibelio Bloch.) Exposed to Cadmium. Physiol Res 45: 479-481, 1996.

ŽIKIĆ RV, ŠTAJN A, OGNJANOVIĆ B, PAVLOVIĆ SZ, SAIČIĆ ZS: Activities of superoxide dismutase and catalase in erythocytes and transaminases in the plasma of carps (Cyprinus carpio L.) exposed to cadmium. Physiol Res 46: 391-396, 1997.

ŽIKIĆ RV, ŠTAJN A, PAVLOVIĆ SZ, OGNJANOVIĆ BI, SAIČIĆ ZS: Activities of superoxide dismutase and catalase in erythocytes and plasma transaminases of goldfish (Carassius auratus gibelio Bloch.) exposed to cadmium. Physiol Res 50: 105-111, 2001. 